\title{
A KÖRNYEZETI PIAC NÉHÁNY MUNKAERÓPIACI ÉS LOGISZTIKAI ÖSSZEFÜGGÉSE AZ ELMÚLT ÉVTIZEDBEN
}

\author{
Dr Ph.D. Gál József \\ egyetemi docens \\ Szegedi Tudományegyetem Mérnöki Kar
}

\begin{abstract}
SUMMARY
Environmental market is much more than environmental protection. We must survey it in its economical, sociological etc. aspects. In my paper I try to find some interesting connecting points how to meet labour market, logistics of material, people and knowledge. Number of employees in this sector is increasing fluently, but you can see big gap among different parts of Europe. We know pollution and environmental protection do not stop at frontiers of countries, therefore must understand flows and find common solutions.
\end{abstract}

\section{Bevezetés}

Napjainkban egyre inkább eitünik a merev határ a mikro- és makroökonómiai felfogások között a környezet és folyamatainak megitélésében, a vállalkozások nem elszigetelt szervezetek, hanem a helyi környezetbe beágyazottan értelmezhetök (Abayné Hamar E. Fábián Gy., 2007).

A logisztikai folyamatok esetén a vizsgálat állandó tárgyát képezi az a valami, amelyet eljuttatunk keletkezési helyéről, a felhasználás helyére. Korunk egyik jelentős kihívása, hogy ez a továbbítási folyamat milyen hatással van a körülvevỏ természeti, gazdasági, jogi és társadalmi környezetre, illetve az hogyan hat rá. Mindenképp egy kölcsönösségen alapuló hatásrendszerről beszélhetünk, amelynek szereplöi a közvetlenül a helyváltoztatáson keresztül is és közvetetten a szélesebb értelemben értelmezhetö környezeti piacon is megjelennek. Jelen publikációmban arra keresem a választ, hogy a környezetvédelem szemüvegén keresztül hogyan értelmezhetők e piac áramlási - logisztikai - folyamatai, elsősorban a munkaeröpiac vonatkozásában. 


\section{Munkaérôpiaci hatás}

Doktori értekezésemben rámutattam arra, hogy a környezetvédelem felismert pozitív externáliái miatt a környezeti piac megítélése Közép- és Kelet-Európában kedvezõ irányba változik, dinamizáló hatása érzékelhetō a munkaerōpiacon. A környezeti piac terjedelmének bövülése jelentős hatást gyakorol a munkaeröpiacra és a területfejlesztésre is. Az OECD országokban a környezeti ipar a teljes foglalkoztatottság 0,5-1\%-át (tisztán környezeti profilú cégek) tette ki 1992-ben (Szlávik J. - Valkó L. [1997-A]). A környezeti piac a gazdaság más területeinél intenzivebb növekedést mutat, így azóta a fejlettebb régiókban ez az arány megtöbbszörözõdött. Érdekes megfigyelni, esetleg mérni azt, hogy a munkahelyek, munkakörök számának változása (személy és a munkaidő szorzata) milyen összefüggést mutat a tudásáramlással, mely szektorokból áramlik a környezeti piac hatókörẻbe munkaerö, milyen képzési szinttel.

A környezetvédelem munkaeröpiaci hatásának elemzésekor az alábbi négy terület különösen nagy szerepet kap:

- a politikai elkötelezettséget tükröző kömyezeti jogi szabályozás,

- a piaci erók,

- önszabályozó mechanizmusok és

- az előzőekre ható nyilvánosság ereje.

A Európai Unióban a környezetvédelem ügye egyre nagyobb súllyal szerepel. A hagyományos szakterületekbe fokozatosan beépül a környezetvédelem, például a víz- és hulladékgazdálkodás. Az aktuális szociál- illetve kömyezetpolitika által gerjesztett munkaterületeken a káros emissziók csökkentése, biogazdálkodás fejlesztése emelhetö ki. A piaci kereslet által indukált feladatokra szerveződő foglalkozások (tanácsadỏi, vevőtájékoztatói szolgáltatások, stb.) is egyre jelentősebbek. Felmérések szerint az EU-ban 2000-es adatok alapján - 3,5 millió munkahelyet köt le a környezetvédelem, melyböl körülbelül 2 millió ember dolgozik a kömyezetbarát technikák, technológiák, megújuló energiaforrások fejlesztésének területén, foglalkozik hulladék reciklálással és természetvédelemmel. A fennmaradó 1,5 millió munkahely a kömyezeti ipar egyéb területein található (Kiss K. [2000]). 
A környezetvédelem integrálódása a gazdasági folyamatokba új impulzusokat ad a társadalmi gondok enyhítésére is munkaerő-piaci hatásán keresztül. A környezeti ipar önállósodási folyamatának megindulása óta viták tárgya, hogy a környezetvédelem negatívan vagy pozitívan hat a munkahelyek megszünésére, illetve keletkezésére. Mindkét álláspont alátámasztható és egyúttal támadható, azonban a következetesen végiggondolt és megvalósított környezetvédelmi programok esetében mindkét hatással számolni kell. A döntő kérdés azonban az egymással ellentétes hatású folyamatok egyenlege. Érdemes vizsgálat alá vetni, hogy mit is kap a munkavállaló a környezettudatos vállalati magatartás pozitiv externáliájaként? (1. ábra) Kijelenthetem, hogy olyan dolgokat, amelyek a munkáltató számára is előnyösek. Egyfajta nagyobb megelégedettség és környezetvédelem iránti motiváltság vagy a munkahelyi balesetek csökkenése, a kevesebb táppénz mind egybevág a vállalatok korszerü müködésének szemléletével.

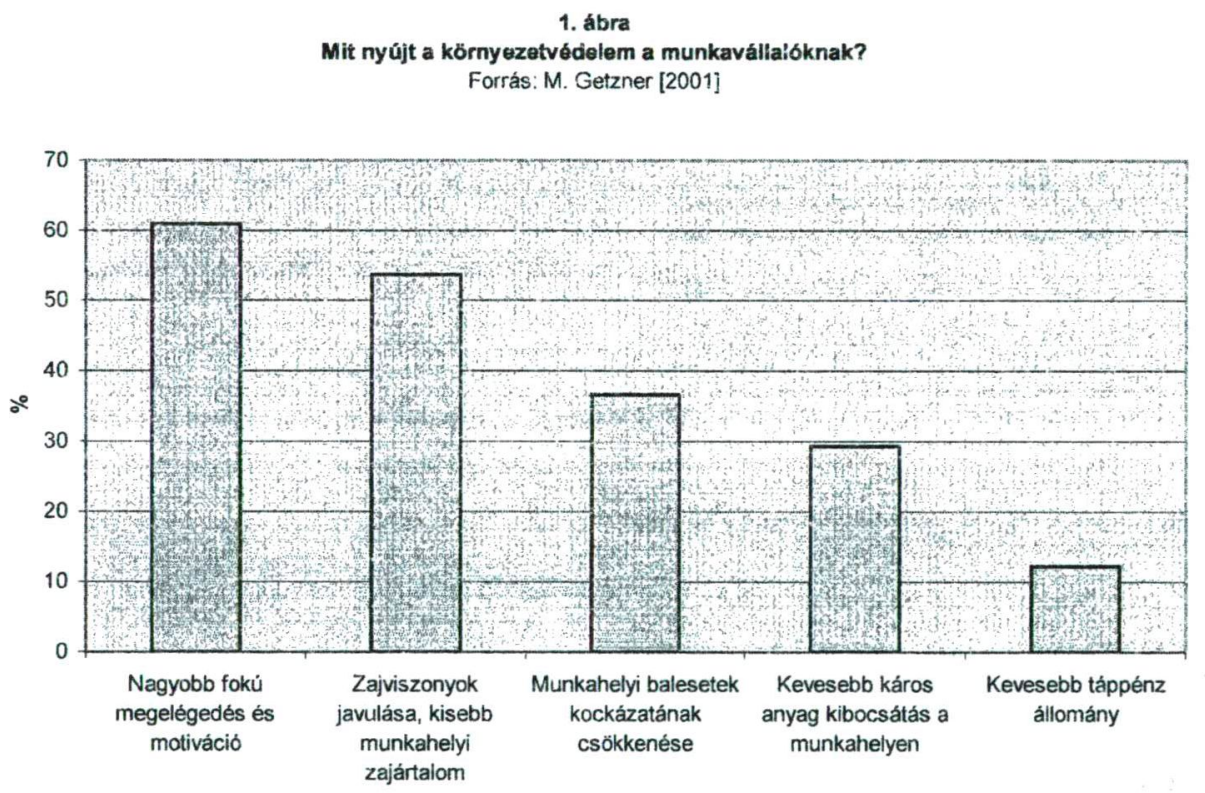

A fejlett országok környezetvédelmi programjai elsősorban regionális és nemzeti szintű környezeti politikákban valósulnak meg, melyekben a szigorodó intézkedések pozitív melléktermékeként jelenik meg. (Gulyás L. 2006) Ez a modell Közép- és Kelet-Európában még kezdetleges formában valósult meg, illetve még várat magára. Más oldalról nézve a foglalkoztatási politika tervezésekor a környezetvédelem a munkahelyteremtő lehetőségek között az elsők között szerepel, melyek költségigénye nem magasabb az egyéb területeken végrehajtott azonos célú programok költségigényénél. Osztrák és német kutatók felhívták a 
figyelmet arra, hogy a kömyezetvédelem munkaerö-intenziv jellege miatt különösen fontos szerepet tölthet be. Szakértök kiemelik, hogy a hulladékgazdálkodás, vizgazdálkodás, a természetes élettereket megỏrzõ programok, valamint a szennyezett területek szanálási feladatai jelentős munkahelỵteremtõ hatással bímak. Egybehangzó véleményeket olvashatunk azzal kapcsolatban, hogy a környezetvédelemmel összefüggő munkahelyek tartós foglalkoztatottságot jelentenek. Ezzel a kijelentéssel szemben még Közép- és KeletEurópa számos területén jelentösek a fenntartások.

Németországban a keresöképes lakosság 2,7\%-a dolgozik környezetvédelemmel kapcsolatos munkahelyen. Kiemelik, hogy a környezeti javak 1\%-os exportjának munkaerőpiaci hatása Németország esetén 1500-2000 új munkahiely teremtését jelenti. Osztrák kutatók (Getzner, M. [2001]) felmérték, mit nyúji a környezetvédelem térnyerése a munkavállalóknak. Az integrált környezetvédelmi intézkedések legjelentösebb minőségi kihatásáról szóló áttekintés alapján $61 \%$ a nagyobb fokú megelégedést ćs motivációt, 53,7\% a zajviszonyok javulását, elsösorban a munkahelyeken, 36,6\% a munkahelyi baiesetek kockázatának csökkenését, 29,3\% kevesebb káros anyag kibocsátást a munkahelyeken és $12,2 \%$ kevesebb táppénzes napot vár, meiyet az 1 . ábra szemléltet.

Ezen a területen Ausztria tevékenysége már most is példamutató. További jelentős foglalkoztatási hatást várnak a széndioxid kibocsátás csökkentésére kidolgozott technológiafejlesztési programtól. Ez, a 34 intézkedést tartalmazó project biztosítja a Torontói Egyezményben vállalt kötelezettségeket, pozitív hozadékaként pedig 12 ezer hosszú távon megmaradó munkahelyet teremt. Hasonló szezonális munkahelyteremtésre a vizsgált régió országaiban szinte nem találunk példát.

Ausztriában a munkanélküliségi ráta a téli hónapokban megemelkedik, ezért külön figyelemre méltó a szezonális ingadozásokat csökkentő ivóvíz-tisztítási és szennyvízkezelési program. A Német Gazdaságkutató Intézet készitett egy felmérést, melyben az üj tartományok nélküli Német Szövetségi Köztársaság területén, a környezetvédelemben foglalkoztatottak számát próbálta meghatározni. Az akkori adatok alapján 550 ezer föben határozták meg ezt az értéket, melyhez az új tartományokban 131 ezer fỏvel számoltak. Ez a létszám a foglalkoztatottak 1,9\%-át jelentette, akiknek $76 \%$-a a német belföldi keresletet elégítette ki. A környezeti piac exportintenzivvé válása miatt ez az arány csökken. A 
szakterület dinamizmusát mutatta, hogy körülbelül 120 ezer fö állása a vizsgált idöpontot megelőző egy évtizedben keletkezett. (Kaiser, H. [1997]).

A szigorodo határértékek fontosak a turizmusban és a szabadidỏ ágazatban is, mivel ezek sikere a vonzó kömyezeten alapszik. Ezt beleértve Angliában 2005-ben a természeti kömyezettel kapcsolatos gazdasági tevékenység 2,68 millió embert foglalkoztatott teljes munkaidőben (Tanyi A. 2007).

1994-ben négy gazdaságkutató intézet összehangolt kutatásban ismételte meg a felmérést (Ritt, T. [2001]). Az adatok alapján a munkavállalók 2,7\%-a számára biztosit foglalkozlatást a környezeti szektor. A nyugati tartományokban számszerüsítve 650 ezer fö, mely 2,3\%-ot jelent, a keleti tartományokban 300 ezer fö, mellyel 4,7\%-os részesedést képvisel a környezeti ipar. Figyelemre méltó az a tény, hogy a kevésbé fejlett keleti tartományokban a környezeti szektorban foglalkoztatottak közel 40\%-a a rehabilitációval, szerkezetátalakítással összefüggő kömyezetvédelmi feladatot végez. 53\%-uk ún. közvetlen környezetvédelmi feladatokat lát el, 47\% foglalkozik kömyezeti piaci termékek elöállításával.

A tanulmány szerzői becsléseket tettek a környezetvédelemben foglalkoztatottak számának meghatározására az ezredfordulóra vonatkozóan. Számitásaik alapján Németországban 1,1 millióra tették az összlétszámot, 785 ezerre a nyugati és 340 ezerre a keleti tartományokban foglalkoztatottakat. A tendencia növekedést mutatott, de a várt mértéket nem érte el. Kételyek megfogalmazódnak a környezetvédelem munkahelyteremtö hatásával kapcsolatban (Zwölfer, R. [1997], Burger, C. [1998]), bár egyre több szakvélemény támasztja alá pozitiv egyenlegét. A téma ugyan nem veszitett aktualitásából, de ilyen struktúrájú és tartalmú újabb adatokat nehéz találni. Felmerül az a dilemma - hasonlóan az ólommentes benzin elterjedését követően az ólmozott kivonása után - hogy az eredetileg környezetvédelmi feladatra címzett munkavállaló közgazdasági értelemben véve közönséges munkavállalóvá válik, hiszen a munka világának természetes részeként jelenik meg, végzi munkáját. Ilyenkor hogyan értelmezhető a munkakörhöz, a munkavállalóhoz réndelt szakismeret, tudás, jártasság? Információlogisztikai értelemben nem egyfajta továbbításról, hanem egy strukturális átrendeződésröl beszélhetünk, melynek hatására kérdésessé válik, hogy egyáltalán értelmezhetö-e a logisztikai folyamat, azaz a keletkezési helyröl a felhasználás helyére továbbitás? 
Ezen közvetlen vagy közvetett módon stimulált helyzetben, a munkaerö-piaci hatások esetén hibás csak a bruttó (számszerủsített) értékekkel (költséggel) számolni, követni érdemes annak társadalomra gyakorolt hatásait is, hiszen a szigorúbb, bár vitathatatlanul elöremutató jogszabályi és piackonform környezet egyes vállalkozásokat olyan mértékben is korlátozhat, hogy tevékenységüket folytatni nem tudják. Ez a helyzet munkahelyek megszünésével jár együtt, ezért ismételten kiemelendö, hogy a munkaerō-piaci hatások esetében csakis az egyenlegből vonható le következtetés.

Az ECOTEC (Analysis of the Size... [2002]) adatai alapján készült egy kimutatás arról, hogy a környezetvédelem mely területein mekkora a foglalkoztatottság. Ezt a 2. ábra mutatja be. Vezetö helyen szerepel 309 ezer fövel a folyékony, majd 307 ezer fövel a szilárd hulladékok kezelése. Ez a két terület az összes foglalkoztatottak 62,7\%-át teszi ki.

\section{2. ábra: Foglalkoztatottak száma a tagjelōlt országok kōrnyezeti piacán}

\begin{tabular}{|l|r|r|r|r|}
\hline \multicolumn{1}{|c|}{$\begin{array}{r}\text { Közvetlen } \\
\text { Üzemeltetés }\end{array}$} & $\begin{array}{r}\text { közvetlen } \\
\text { beruházás }\end{array}$ & $\begin{array}{r}\text { közvetett } \\
\text { üzemeltetés }\end{array}$ & összesen \\
\hline légszennyezés & 35700 & 97300 & 59700 & 192700 \\
\hline folyékony hulladék & 113300 & 124100 & 71400 & 308800 \\
\hline Szilárd hulladék & 230500 & 30500 & 46200 & 307200 \\
\hline zaj és rezgés & 1300 & 900 & 300 & 2500 \\
\hline adminisztráció & 76500 & 54600 & 29600 & 160700 \\
\hline Egyéb & 3800 & 2900 & 3100 & 9800 \\
\hline összesen & $\mathbf{4 6 1 ~ 1 0 0}$ & $\mathbf{3 1 0 3 0 0}$ & $\mathbf{2 1 0 3 0 0}$ & $\mathbf{9 8 1 ~ 7 0 0}$ \\
\hline
\end{tabular}

Forrás: Analysis of the Size ... ECOTEC [2002]

Magyarország a vizsgált terület élen járó országai közé sorolható. Egy kutatás (Kiss K. [2000]) alapján a Környezetgazdálkodási Intézet (KGI) szakemberei azt a következtetést vonták le, hogy a jelentős környezethasználó vállalatok száma Magyarországon mintegy 2500-ra volt tehetô, amely vállalatok legalább 4000 fö függetlenített környezetvédelmi szakembert alkalmaznak. A kömyezetvédelmi ipar és szolgáltatói vállalkozásokban dolgozók létszámát pedig 1500 före becsülik. Ez összesen körülbelül 5500 föt érint. Ha csak az EU-hoz csatlakozó országokat tekintjük (Analysis of the EU Eco-Industries... [2002]) a közvetlen 
környezetvédelemmel foglalkozók óriási. 770 ezren a szennyezés menedzsmentben, 460 ezren a direkt müködtetésben és 310 ezren a beruházásokban dolgoznak. Szektorok szerinti megosztásban 50\%-ra tehetỏ a hulladékokkal, $25 \%$ a szennyvizzel foglalkoznak. Magyarország mellett kiemelendö még Lengyelország és Csehország is.

\section{Gazdaságracionalizáló hatás}

A környezetvédelmi tevékenységet nem lehet egyetlen klasszikus gazdasági ágazatba sem besorolni. Egyes területeken, dinamikus fejlödésre lehet számitani, melynek motorja a gazdaság racionalizáló mechanizmusa. Környezeti piaci elemzök rámutatnak arra, hogy az EU-s és nemzeti kornányzati elszántság is kedvező lehetőséget biztosít a vállalatok szamára az elvárt környezeti teljesítmény megvalósításához. Amennyiben a jogi szabályozás és az öszlönző, motiváló piaci háttér együttesen jelen van, kialakul a „win-win” típusú szituáció, amely a nemzetgazdaság és a tágabb régió számára is kedvező és kívánatos. A logisztika itt megjelenik az alapanyagok, a félkész- és késztermékek, fokozottan az energiahordozók és nem utolsó sorban a kibocsátások, hulladékok összefüggésében, hiszen ezeket is a keletkezés, a felhasználás, az ártalmatlanitás, a deponálás, stb. összefüggéseiben, tehát teljes életciklus személetében kell értelmezni.

A gazdaság reakciója szempontjából érdemes megvizsgálni az additiv és az integrált környezeti technikák alkalmazása iránti fogadókészséget, a megvalósíthatósággal kapcsolatos teher és kötelezettségvállalás mértékét. „Egyrészröl felmerül a káros környezeti externáliak internalizálásának igénye - mint a konzekvens környezetpolitikák rendezö elve -, másrészt a környezetszabályozás nem nélkülözheti az „ostor és a mézesmadzag” eszközkombinációt." (Valkó L. [1994]) Ilyen módon fedi le egymást a környezeti piacra szakosodott vállalkozások és a környezeti érdeke harmonizálását magára válialó kormányzat elképzelése. A vállalkozások részéröl egyre gyakrabban felmerülö igény, hogy valamilyen formában egységesíteni kell a szervezethez füződő gazdasági, társadalmi és környezeti elemeket (Mathias A. - Tóth G., 2007).

A környezetpolitika célja egyértelmü, hiszen a hatékony megelözést egyetlen utólagos kompenzáló, helyreállító technológia sem képes jobban megvalósítani. Az additív környezettechnika, technológia szerepe azonban vitathatatlan a gazdaság mindennapjaiban. 
Eljárásai, technológiái jól definiálhatók és jellemezhetők. Fő tulajdonságuk az, hogy a termelési folyamatokhoz kiegészítésként hozzáépülnek, magában a föfolyamatban nem okoznak lényeges változást, így csökkentik a termékek vagy folyamatok kömyezetet terhelö maradványanyagait vagy a kiáramló anyagok a környezetet kevésbé károsító, könnyebben ellenőrizhető formában kerülnek ki. Tipikus megjelenési formái a filterek, fuistgáztisztító eljárások, katalizátorok, stb.

A gazdasági szféra motiváltság hiányában csak akkor mutat hajlandóságot használatára, ha jogszabályi kötelezettség írja elő, vagy a társadalom nyomást gyakorol a kibocsátóra. A vállalkozások ellenérvei között szerepel, hogy az utólag vagy kiegészítöként felszerelt berendezések beruházási tételként jelennek meg, továbbá müködtetésük is költséget jelent, melyet az árba valamilyen formában be kell építeni. Ez az álláspont tipikus Közép- és KeletEurópában, a piac nem mindig fogadja el, igy a kötelezỏn felüli védelmet vállalỏ cég adott esetben versenyhátrányba kerül. Szeretném megjegyezni, hogy ez a vállalati félelem túlzott, az esetek jelentõs részében nem olyan mértékü a fajlagos plusz költséghányad, mint azt elôre prognosztizálják. A piac más vállalatai is általában megteszik a szükséges környezetvédelmi lépéseket, mert rájuk nézve is kötelezö, illetve megítélésük is kedvezőtlenné válhat a konkurenciával szemben. Másik aspektusból vizsgálva a folyamatokat, a környezetet kevésbé használó és terhelő megoldások anyag- és energiafelhasználás, hulladékkezelés, stb. terén eleve költségcsökkenést jelentenek, ezáltal máris kivánatosak a vállalkozás számára. A döntésnél komplex mérlegelés szükséges, az elhamarkodott -. csak költségeket látó menedzsèri szemlélet okozhat valós veszteséget a cégnek.

$\mathrm{Az}$ integrált környezeti technikák esetében alapvetö követelmény, hogy az additív technikák hátrányait kiküszöböljék, illetve csökkentsék. Az integrált környezeti technikák fogalma még formálódóban van, azonban néhány jellemzője, kritériuma egységesnek tekinthető. A problémakört termelésintegrált és termékintegrált oldalról is lehet vizsgálni, de mindkét esetben megfogalmazódnak az alábbiak:

- kevesebb energiát és anyagi erõforrást igénylő termelési eljárásokra történő átállás,

- hulladékhő felhasználás következtében takarékosabb energiagazdálkodás,

- a primer recycling, illetve az anyagforgalom folyamaton belüli szabályozott megvalósítása,

- a maradványanyagok képződésének csökkentése, a továbbhasznosítás lehetőségének vizsgálata, 
- a környezetre káros anyagok kiváltása kevéssé szennyezőkkel,

- folyamatok cseréje a környezetet kevésbé terhelőkkel,

- újrafelhasználás, illetve továbbhasznosítás ösztönzése.

Földrajzi területtől függetlenül igaz, hogy az intenzív technikák vásárlása általában nagyobb forrást igényel, mint az additiv technikáké. Viszonylag ritkán fordul elö, hogy egy ilyen léptékü beruházásra csupán környezetvédelmi motiváltságból kerül sor. Egyre inkább összehasonlitásra érdemes tényezổ az elszállítás, elhelyezés, ártalmatlanítás. Sajnálatos módon erre vonatkozóan negatív példákat is találunk, sőt a feketegazdaság is "fantáziát" látott benne. Megjegyzendỏ azonban, hogy a környezeti ipar fejlődése, innovációs hajtóereje, olyan pozitív hozadékot jelent, amely beépülve az új technikába, technológiába, magában hordozza - így versenyelönyt kínálva - a környezetkímélö megoldásokat. Az additív és az integrált technikák nem jelentik egymás alternativáit. A folyamatok és termékek ökológiai optimalizálása során sok esetben csak a két megoldás együrtes alkalmazása, kombinációja lehet hatékony. A két fogalom mögött álló technikai-technológiai háttér a környezeti mérnöki tevékenység paradigma-váltásaként jelenik meg a vizsgált térség országaiban. A primer emisszióra, illetve hulladékokra figyelö szemléletről a forrásorientált szemléletre történő átállásnak vagyunk tanúi. Ennek intenzitása, fejlettségi szintje jelentős regionális eltéréseket mutat.

Az új technikák, technológiák bevezetése a cégek számára tranzitköltségekkel jár, melyek leggyakrabban licenc-dijak, kutatási-fejlesztési kiadások is, információ beszerzésének költsége formájában jelennek meg. Számos anyag- és energiafelhasználást racionalizáló program megvalósítására központi támogatás pályázható. Engedélyeztetési eljárásuk is egyszerübb, hiszen máshol már bevezetett, bizonyos értelemben véve standard technikákról van szó. Az integrált technikák ezzel szemben magukban hordozzák a jelentös forrásigényt; hiszen itt nem csupán egy kiegészítő elem felszereléséről van szó, hanem markánsan új technikáról, technológiáró!.

A másik megjelenö költségelem az alkalmazkodási- és átállási költségek csoportja. Ide sorolható például az oktatási költség, melynek mértéke a meglévô és az új technológia közötti különbség függvénye. Amennyiben az új technológia jelentősen megváltoztatja a termelési folyamatot, annak összeegyeztethetősége a régi, megmaradt technológiai résszel (pl. szük keresztmetszet kiküszöbölése, más készletezési módszer alkalmazása), egyes 
alapanyagok, félkész termékek körének megváltozása, esetlegesen üj típusú hulladékok képzỏdése új helyzet elé állíthatja a vållalkozást.

A bevezetendő integrált környezeti technika, technológia kockázata nagyobb, hiszen még nem kipróbált, bizonyított berendezésről vagy módszerről van szó. A berendezés „gyermekbetegségei", meghibásodási valószinüsége kevésbé ismert, ezért a termeléskiesés rizikója is számba veendō, hiszen az integrált technika leállása esetén a termelö, szolgáltató folyamat is leáll. A felmerült kételyek miatt az integrált technikák iránti fogadókészség gyakorta alacsony szintũ, ezért referencia projektekkel, finanszírozási segítséggel ösztönözni kell a vállalatokat.

\section{4. Összefoglalás, kōvetkeztetések}

Kutatásom során arra a megállapitásra jutottam, hogy Közẻp- és Kelet-Európa országaiban még igazán nem ismerték fel a környezetvédelemben rejlö munkahelyteremtõ potenciált. A kormányzatok aktívabb közremüködése, az EU direktíváinak kényszerítő hatása miatt megvalósulni látszik, azonban egyelōre a minimum követelmények teljesitése kap prioritást a prevencióval, a hosszú távú gondolkodással szemben. A tudás és a munkaerő áramlása, logisztikája nem mutatható ki jelentös áramlatként, azonban a multinacionális cégek térségbeli terjeszkedésére érdemen odafigyelni.

Érdemes azon is elgondolkozni, hogy egy-egy környezetvédelmi céllal bevezetett eljárás, termék meddig tekinthetỏ annak. Példaként emlitem meg az ólommentes benzint, amely környezetkímélő változatként került bevezetésre. Ma Magyarországon csak ólommentes benzint lehet kapni, így ez a termék átkerült a közönséges javak kategóriájába. Új kérdésként fogalmazódik meg, hogy a környezeti piac elemeinek számbavételekor, logisztikai folyamatainak megvalósulásakor most is figyelembe kell-e venni?

Már korábban is utaltam arra, hogy egyes esetekben az országhatáron túli környezetvédelmi célú beruházások hatékonysága nagyobb lehet mind a beruházás helyén, mind a beruházó ország számára. Ebben az esetben makrologisztikai folyamatról van szó; amelynek szerepe.az egységesedő Európában egyre nagyobb lesz. 


\section{Felhasznált irodalom}

1. Abayné Hamar Enikő - Fábián Gyula (2007.11.30.): Gazdasági környezet és versenyképesség alakulása a magyar mezögazdaságban http://www.nkfp014.hu/dokumentumok/nkfp/krfl 85 .doc

2. Analysis of the EU Eco-Industries, their Employment and Export Potential [2002], A Final Report to DG Environment, ECOTEC Research \& Consulting Limited,United Kingdom,http://europa.eu.int/comm/environment/enveco/industry employment/main report.pdf p. 1-104. 2003.06.30.

3. Analysis of the Size and Employment of the Eco-Industries int he Candidate Countries [2002], A Final Report to DG Environment, ECOTEC Research \& Consulting Limited,UK, bttp://europa.eu.int/comm/environment/enveco/industry employment/ecotec_candid ate countries.pdf, 2003.06.30.

4. Burger, Christina [1998]: Beschäftigung durch Unweltschutz, 10/1998, Oktober, Wien, Österreich, p. i 8-19.

5. Getzner, Michael [2001]: Saubere Wunder, Wirtschaft \& Umwelt, 2/2001, Wien, Österreich, p. 18-20.

6. Gulyás László (szerk. 2006): A humán eröforrás menedzsment alapjai. JATE Presz-Szegedi Egyetemi Kiadó. Szeged

7. Kaiser, Helmut [1997]: Environmental market in Eastern Europe displays divergent growth says report, Water \& Environment International, Volume 6, No 46, 1997. March, Redhill, UK, p.8-23.

8. Kiss Károly (szerk.) [2000]: A környezetvédelem hatása a foglalkoztatottságra (összefoglaló tanulmány), Budapest, 2000. június

9. Mathias Anna - Tóth Gergely (2007.12.01): Környezeti és fenntarthatósági (GRI-) jelentések, http://tranzit.hu/1/kornyezetvedelem/2003/3/2003-04-01/kornyezeti-es-fenntarthatosagi-grijelentesek

10. Ritt, Thomas [2001]: Gute Umwelt - bessere Jobs, Wirtschaft \& Umwelt, 2/2001, Wien, Österreich, p. 14-17.

11. Szlávik János - Valkó László [1997-A]: A környezeti szektor integrációs nézỏpontból, Társadalmi Szemle, 1997. 11. szám, p. 81-94.

12. Tanyi Anita (2007.12.01.): A jó környezetvédelmi szabályozás kedvezỏen hat a versenyképességre, http://www.levego.hu/letoltes/kapcsolodo anyagok/szabalyozas kv0611.pdf

13. Valkó László [1994]: Kísérlet a környezeti piac meghatározására (kandidátusi értekezés), Budapest

14. Zwölfer, Renate [1997]: Umweltschutz schafft Arbeitsplätze - Mythos oder Realität? Umweltschutz, 4/1997, April, Wien, Österreich, p. 10-15. 